\title{
Life cycle assessment of chitosan production in India and Europe
}

\author{
Ivan Muñoz ${ }^{1}$ - Cristina Rodríguez ${ }^{2} \cdot$ Dominique Gillet $^{3} \cdot$ Bruno M. Moerschbacher ${ }^{4}$
}

Received: 9 December 2016 / Accepted: 20 February 2017 / Published online: 11 March 2017

(C) The Author(s) 2017. This article is published with open access at Springerlink.com

\begin{abstract}
Purpose The aim of this article is to present the first life cycle assessment of chitosan production based on data from two real producers located in India and Europe. The goal of the life cycle assessment (LCA) was to understand the main hot spots in the two supply chains, which are substantially different in terms of raw materials and production locations.

Methods The LCA is based on consequential modelling principles, whereby allocation is avoided by means of substitution, and market mixes include only flexible, i.e. nonconstrained suppliers. The product system is cradle to gate and includes the production of raw materials, namely waste shells from snow crab and shrimp in Canada and India, respectively, the processing of these in China and India and the manufacture of chitosan in Europe and India. Primary data for chitin and chitosan production were obtained from the actual producers, whereas raw material acquisition as well as waste management activities were based on literature sources. The effects of indirect land use change (iLUC) were also included.
\end{abstract}

Responsible editor: Ian Vázquez-Rowe

Electronic supplementary material The online version of this article (doi:10.1007/s11367-017-1290-2) contains supplementary material, which is available to authorized users.

Ivan Muñoz

ivan.munoz@1ca-net.com

1 2.-0 LCA Consultants, Rendsburggade, 14, 4.315B, 9000 Aalborg, Denmark

2 Greendelta GmbH, Müllerstrasse, 135, 13349 Berlin, Germany

3 Mahtani Chitosan Pvt., Ltd., Dari Village, Veraval, Gujarat 362265, India

4 Institute for Biology and Biotechnolgy of Plants, University of Münster, Schlossplatz 8, 48143 Münster, Germany
Impact assessment was carried out at midpoint level by means of the recommended methods in the International Life Cycle Data (ILCD) handbook.

Results and discussion In the Indian supply chain, the production of chemicals $(\mathrm{HCl}$ and $\mathrm{NaOH})$ appears as an important hot spot. The use of shrimp shells as raw material affects the market for animal feed, resulting in a credit in many impact indicators, especially in water use. The use of protein waste as fertilizer is also an important source of greenhouse-gas and ammonia emissions. In the European supply chain, energy use is the key driver for environmental impacts, namely heat production based on coal in China and electricity production in China and Europe. The use of crab shells as raw material avoids the composting process they would be otherwise subject to, leading to a saving in composting emissions, especially ammonia. In the Indian supply chain, the effect of iLUC is relevant, whereas in the European one, it is negligible.

Conclusions Even though we assessed two products from the same family, the results show that they have very different environmental profiles, reflecting their substantially different supply chains in terms of raw material (shrimp shells vs. crab shells), production locations (locally produced vs. a global supply chain involving three continents) and the different applications (general-purpose chitosan vs. chitosan for the medical sector).

Keywords Chitin - Chitosan - Consequential life cycle assessment $\cdot$ Life cycle assessment

\section{Introduction}

Chitosan refers to a family of polysaccharides obtained by partial de-N-acetylation of one of the most abundant renewable resources on Earth, chitin. Chitin is found in the 
exoskeletons of insects and crustaceans such as shrimp and crab, in the endoskeletons of mollusks such as squid, in many invertebrates such as in the egg shells of nematodes, in the cell walls of fungi and some diatom algae. Recently, chitosan has received considerable attention as a functional biopolymer with a wide range of applications in food, agriculture, medicine, pharmaceutics and cosmetics, taking advantage of its various interesting physicochemical and biological properties. Chitosan is water-soluble; non-toxic; biocompatible; and exhibits antibacterial, antifungal and antitumor activities, as well as immuno-enhancing effects on animals (Jeon et al. 2000; Kim and Rajapakse 2005), elicits increasing protective responses in various plants (Vander et al. 1998; Cabrera et al. 2006) and possesses antimicrobial activities against a wide spectrum of phytopathogens (Kendra and Hadwiger 1984).

The chitosan market is a very confidential one; however, an estimated $2000 \mathrm{t}$ of chitosan is produced annually (GIA 2005), mostly from shrimp and crab shell chitin. Currently, the largest market by far for chitosan is as fat blocker, even though its effectiveness in this area lacks scientific backing (Jull et al. 2008). Another commercial application for bulk chitosan is its use in water filtration, as a coagulant/flocculant. However, the most promising applications for chitosan lie in the life sciences, including plant disease protection, wound healing and drug delivery (Agnihotri et al. 2004; Paul and Sharma 2004; Bautista-Baños et al. 2006).

The environmental impacts of chitosan production remain poorly studied to date. In the area of life cycle assessment (LCA), we have been able only to identify two peerreviewed studies addressing to some extent this material. Beach et al. (2012) assessed several options for harvesting microalgae by flocculation, namely the use of chitosan, ferric sulphate and alum. These authors built a life cycle inventory (LCI) for chitosan produced from average crustacean shell, based on literature, patents and interviews with manufacturers. In that study, chitosan was found to be superior from an environmental point of view to ferric sulphate and alum as a flocculant for microalgae harvesting. Leceta et al. (2013) compared two food packaging systems based on polypropylene and chitosan, respectively. In this case, the LCI data were obtained entirely from literature sources, and the results showed trade-offs between impact categories. This short list of studies shows that little data are available on chitosan production from a sustainability perspective; the two published studies do not have chitosan as the focus of their research but as a raw material for a given industrial application. Also, the LCI data used in these studies originated mainly from literature and secondary sources rather than from primary industrial data. In this article, we present what to our knowledge constitutes the first LCA applied to chitosan production based on primary data from two real producers, located in Europe and India, respectively. The goal of the study is to examine two different chitosan supply chains in order to understand their main hot spots. It must be highlighted that it is not a goal of the study to establish which chitosan is more sustainable, since the products assessed target different markets, as explained in the following section.

\section{Goal and scope}

The LCA study was carried out with the ISO 14040 and 14,044 standards as main methodological guidelines (ISO 2006a,b), and consequential modelling principles were used in the inventory analysis, as defined in Ekvall and Weidema (2004) and Weidema et al. (2009). The software used was SimaPro version 8.1.1 (Pré Consultants 2016). The intended audience of the study was in first instance the partners of the Nano3bio research project as well as the European Commission, which funded this research, as well as the two chitosan producers involved, as they could be interested in using the results of this study to define strategies to improve the environmental profile of their products.

As already stated in Sect. 1, the goal of this study was not to determine which chitosan has a better environmental performance. This is due to the fact that the two products assessed target different markets; the chitosan produced in India is used in applications such as agriculture, amongst others, whereas the European producer is entirely focused on the medical sector.

\subsection{Chitosan supply chains and production processes}

Production of general-purpose chitosan in India is modelled according to data from Mahtani Chitosan, which produces $50 \mathrm{t}$ chitosan annually, on the coast of Gujarat. Production of chitosan for the medical sector in Europe is modelled according to data from a company that prefers to remain anonymous, and for this reason, we neither disclose its location in Europe nor part of their primary inventory data due to confidentiality reasons.

Mahtani's raw material is shrimp shell coming exclusively from the wild catch of shrimps (Penaeus spp., Metapenaeus spp. and Parapenaeus spp.) in the Arabian Sea. Waste shells are transported from seafood-processing plants in the vicinity to Mahtani's facility, where they are first converted to chitin. This involves the steps of demineralisation, using dilute hydrochloric acid $(\mathrm{HCl})$, and protein removal, using a dilute sodium hydroxide $(\mathrm{NaOH})$ solution. The resulting chitin is then subject to a deacetylation step, using highly concentrated (40-50\%) solutions of $\mathrm{NaOH}$ at high temperatures. These processes generate wastewater, which is treated on-site before being discharged to the sea. Extracted protein, in a sludge form, is recycled locally as a fertilizer, whilst calcium salts are disposed of in a landfill or used as road-filling material in Mahtani’s facilities. 
The supply chain of the European producer starts in New Foundland, Canada, where the raw material is obtained, namely shells of snow crab (Chionoecetes opilio). Waste shells are dried and shipped to Qingdao in China, where chitin is produced following the same steps of demineralisation and deproteinisation already described. Chitin is then shipped to the European producer, which applies deacetylation to obtain chitosan. The protein sludge originated during chitin production is used as animal feed in China, whilst wastewater and waste $\mathrm{NaOH}$ generated during chitosan production in Europe are sent to treatment.

\subsection{Functional unit, system boundaries and consequential LCI modelling}

Figures 1 and 2 show a flow diagram for the two product systems, as described in Sect. 2.1. LCA is applied with cradle-to-gate boundaries, where the functional unit is demanding additional $1 \mathrm{~kg}$ of chitosan at the manufacturer's gate. The system includes production and transport of the required raw materials, the processing to obtain chitosan and all the supporting activities (production of energy carriers, auxiliary materials, etc.).The inventory includes infrastructure (buildings) associated with the manufacturing facilities in India, China and Europe, but due to lack of primary data on this subject, this was done with generic data from the ecoinvent database (ecoinvent Centre 2016) for the organic chemical industry.

Figures 1 and 2 show how we have applied two key aspects of consequential LCI modelling, namely substitution (also called system expansion) and identification of marginal suppliers. In terms of substitution, several activities in the product system provide by-products, which substitute other products in the market (shown in dashed-line boxes in Figs. 1 and 2). As for identification of marginal suppliers, supply of shrimp and crab shells is considered constrained, given that an increase in demand for these materials is not expected to be met by an increase in supply, since the determining product for the seafood industry is not waste shells, but seafood meat. Thus, demand for waste shells affects the marginal use for these materials, which is as animal feed in the case of shrimp, and in the case of snow crab, based on GAMS (2010), we consider compost production as the marginal use. Further details on modelling of marginal suppliers and substitution in the product system are given in Sect. 3 .

\subsection{Land use change}

Chitosan is a bio-based product, and although its raw material is waste from fisheries, it has an indirect link to land use change, given that it affects the market for animal feed, through its raw material in the case of shrimp, through by-products in the case of crab. In order to quantify this effect for chitosan production, we have applied the model for indirect land use changes (iLUCs) developed by Schmidt et al. (2015).

\subsection{Impact assessment methods}

The impact categories and characterisation models used are those suggested by the International Life Cycle Data (ILCD) handbook (JRC-IES 2010), at midpoint level. In the climate change impact category, biogenic $\mathrm{CO}_{2}$ emissions from degradation of organic matter in crab and shrimp (fat, protein, etc.) and from the use of biomass as fuel were considered as having a net GWP-100 of zero, as this carbon was sequestered in the recent past and released back to the atmosphere relatively quickly; for this reason, it is considered not to contribute to a net increase in atmospheric $\mathrm{CO}_{2}$ concentrations. However, biogenic $\mathrm{CO}_{2}$ emissions caused by land use change, i.e. those released from standing biomass and soils due to clearing of land to increase crop production, were considered as having a GWP-100 of 1, as this is carbon that has been stored for longer time frames and is considered a net addition to atmospheric $\mathrm{CO}_{2}$. Also, $\mathrm{CO}_{2}$ released during treatment with acid of calcium carbonate in shells was considered as of fossil origin. This is in in line with the labelling of carbon from carbonate rocks according to the ecoinvent database (Weidema et al. 2013).

We replaced the Swiss Eco-scarcity method (Frischknecht et al. 2008) used for impacts on water resources by the water use indicator from ReCiPe (Goedkoop et al. 2013), which addresses water on physical (volume) units, rather than on a water scarcity basis. It must be highlighted that water used to move turbines in hydropower plants were not considered as water use, given that this use does not lead to either depletion or degradation of freshwater resources.

\section{Data sources and inventory analysis}

In this section, we describe the main data sources and assumptions made in the inventory analysis. The detailed inventory tables for each chitosan supply chain can be found in the supplementary material.

\subsection{General activities and background system}

Several materials and by-products involved in the chitosan supply chain affect the markets for animal feed. According to Schmidt and Dalgaard (2012, Sect. 7.2), the marginal source of animal feed can be broken down to one market for feed protein and one market for feed energy. The most likely sources of feed protein and feed energy to be affected have been identified as soybean meal from Brazil and barley from Ukraine (Schmidt 2015). Inventory data for soybean meal and barley systems were obtained from Schmidt (2015). One of 
Fig. 1 Product system for production of general-purpose chitosan in India. Grey boxes indicate the constrained activities, which are not included in the system

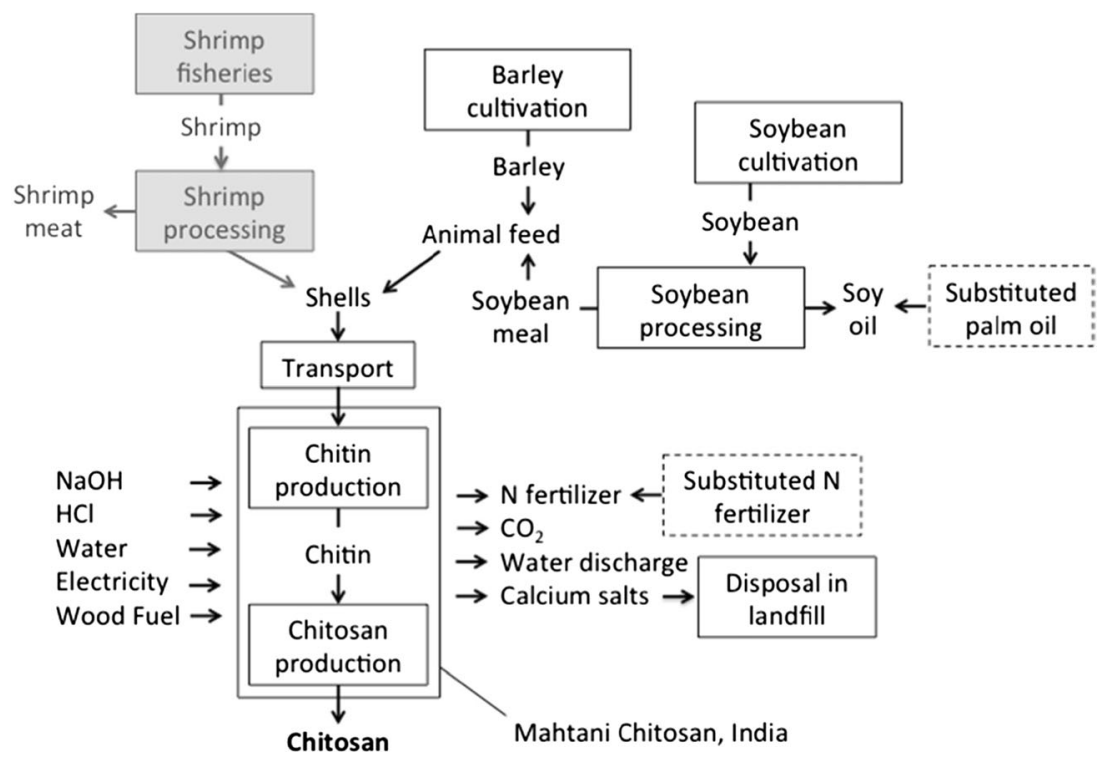

the key aspects of soybean meal is that its production leads to soy oil as co-product, which is assumed to substitute palm oil in the market (Schmidt 2015).

In order to assess iLUC with the model by Schmidt et al. (2015), this requires quantifying the potential production capacity, measured as productivity weighted hectare years (ha*year-eq) of each land using activity. This unit measures potential net primary production $\left(\mathrm{NPP}_{0}\right)$ in the considered region relative to the global average. The ha*year-eqs were defined for each of the crops involved in the product system, namely barley in Ukraine, soybean in Brazil and palm fruit in Malaysia/Indonesia. Based on Haberl et al. (2007), the global average $\mathrm{NPP}_{0}$ for arable land is $6.11 \mathrm{t} \mathrm{C} / \mathrm{ha} /$ year and the average ha*year-eqs for the mentioned crop-country location combinations were estimated as $0.82,1.47$ and 2.0 ha*year-eqs, respectively.

In the foreground system, electricity production mixes were defined for four countries/regions involved in the chitosan supply chains, namely Canada, China, India and the EU, plus three countries involved in animal feed production systems, namely Brazil, Malaysia and Indonesia. Electricity production mixes were defined looking at long-term marginal supply, based on current production compared to forecasts to 2020 for each country/region (Muñoz et al. 2015).
Fig. 2 Product system for production of chitosan for the medical sector in Europe. Grey boxes indicate the constrained activities, which are not included in the system. The substituted animal feed system corresponds to the one in Fig. 1, not shown in this figure for simplicity

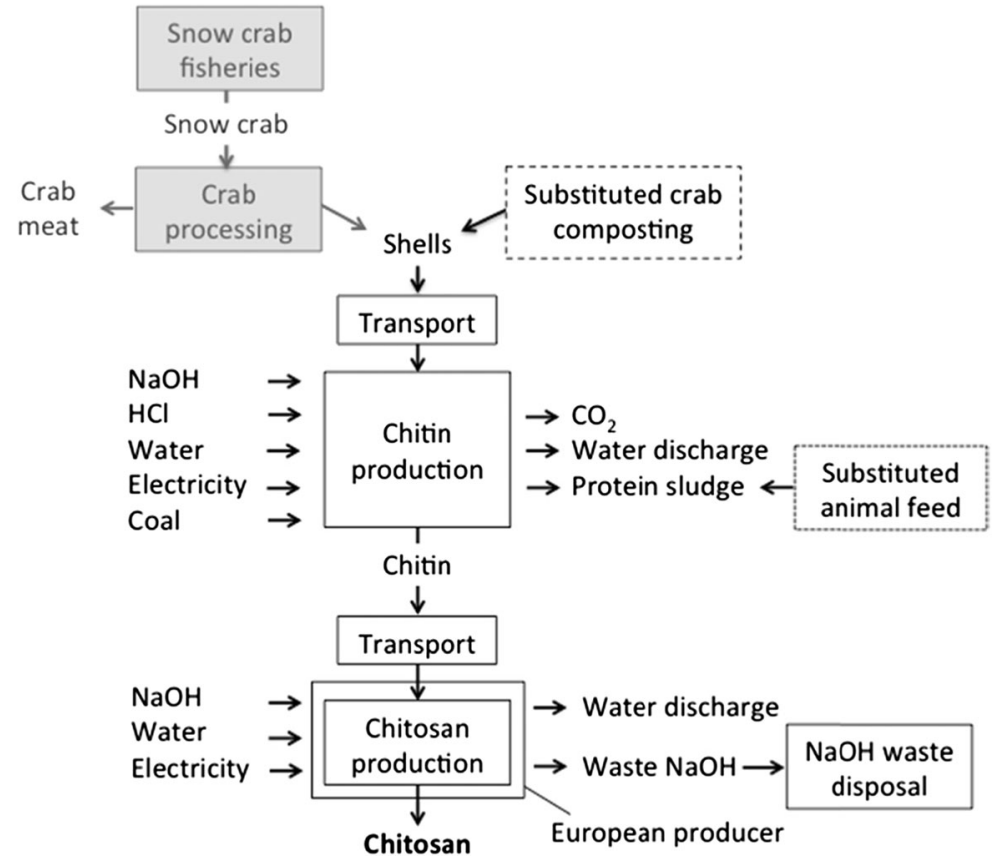


All activities in the background system were modelled with the consequential version of the ecoinvent database v.3.1 (ecoinvent Centre 2016).

\subsection{Indian chitosan supply chain}

As described in Sect. 2.2, diverting shrimp shells from animal feed to chitosan production affects the animal feed market by inducing production of an equivalent amount of feed energy and feed protein per kilogram of shell. Based on Mahtani's characterisation of shrimp shells and the average nutritional composition given by Feedipedia (INRA, CIRAD, AFZ and FAO 2015), it was estimated that $1 \mathrm{~kg}$ shells in wet weight (75\% moisture) contains $2.1 \mathrm{MJ}$ feed energy equivalents and $0.16 \mathrm{~kg}$ protein equivalents.

Chitin production requires $33 \mathrm{~kg}$ shrimp shells in wet weight per $\mathrm{kg}$ chitin. Shells are transported from the shrimp-processing factory using a tractor with an open trailer, consuming $1.4 \mathrm{~L}$ diesel per tonne shrimp shells. The production process consumes, on a per $\mathrm{kg}$ chitin basis, $0.02 \mathrm{~L}$ diesel for bulldozer operation, $8 \mathrm{~kg} \mathrm{HCl}$ $32 \%, 1.3 \mathrm{~kg} \mathrm{NaOH}, 1.3 \mathrm{kWh}$ electricity and $167 \mathrm{~L}$ freshwater. Land occupation by Mahtani's facilities is $0.045 \mathrm{~m}^{2} \mathrm{yr}$ per $\mathrm{kg}$ chitin. The release of $\mathrm{CO}_{2}$ from calcium carbonate in shells during the treatment with acid is estimated at $0.7 \mathrm{~kg} \mathrm{CO}$ per $\mathrm{kg}$ chitin, based on their carbon content and stoichiometry. Solid waste from chitin production includes $1.5 \mathrm{~kg}$ calcium salts $/ \mathrm{kg}$ chitin, which were modelled as sent to an inert landfill, and $4 \mathrm{~kg}$ of protein sludge, expressed in dry mass, which are used as fertilizer. The use of protein sludge displaces the use of mineral $\mathrm{N}$ fertilizers, assuming that $1 \mathrm{~kg}$ nitrogen in organic sludge replaces $0.4 \mathrm{~kg}$ nitrogen in mineral fertilizers (Boldrin et al. 2009). The LCI for application of sludge as fertilizer includes emissions of dinitrogen monoxide, ammonia and nitrogen oxides based on IPCC (2006) as well as $\mathrm{CO}_{2}$ from the mineralisation of organic carbon in proteins.

Chitosan production requires $1.4 \mathrm{~kg}$ chitin per kg chitosan. Mahtani reports the following auxiliary inputs, per $\mathrm{kg}$ chitosan: $5.18 \mathrm{~kg} \mathrm{NaOH}, 1.06 \mathrm{kWh}, 31 \mathrm{MJ}$ wood fuel and $250 \mathrm{~L}$ water. Land occupation was estimated at $0.043 \mathrm{~m}^{2}$ yr. Finally, the carbon storage in chitosan, based on its empirical formula $\left(\mathrm{C}_{6} \mathrm{H}_{11} \mathrm{NO}_{4}\right)_{\mathrm{n}}$, is quantified as $1.64 \mathrm{~kg} \mathrm{CO} / \mathrm{kg}$. The same figure is used in the LCI of chitosan produced in Europe.

Wastewater generated in the chitin and chitosan production steps is treated on-site by means of neutralisation, primary settling, biological treatment and sand filtration. Emissions to seawater from the treated effluent are included in the inventory (see supplementary material).

\subsection{European chitosan supply chain}

The diversion of crab waste to chitosan production displaces its current use (or disposal method), namely composting and the subsequent use of compost as fertilizer. We did not have access to actual data from composting plants in Canada, and we modelled this process based on publicly available data. Based on GAMS (2010), an estimated distance of $25 \mathrm{~km}$ by truck was assumed to transport crab waste to the composting plant. Composting energy and equipment use, including plant buildings, etc., were obtained from the ecoinvent database (Nemecek and Kägi 2017), which provides data for windrow composting in Switzerland. Emissions associated to the composting process, namely $\mathrm{CO}_{2}$, dinitrogen monoxide, methane, ammonia, nitrogen oxides and hydrogen sulphide, were estimated using mass balances, based on snow crab waste composition as reported by GAMS (2010) and several literature sources (Muñoz et al. 2008; IPCC 2006; Soliva 2001; FAO and IFA 2001; Smith et al. 2001; Mathur et al. 1988). Displacement of mineral N fertilizer by compost was modelled as described for protein sludge in Sect. 3.2. Displacement of $\mathrm{P}$ fertilizer assumed that $1 \mathrm{~kg} \mathrm{P}$ in compost replaces $0.95 \mathrm{~kg} \mathrm{P}$ in mineral fertilizer (Boldrin et al. 2009). Crab compost was also assumed to displace limestone use, based on a 1:1 equivalence.

Drying of crab shells was also based on generic LCI data, in particular on the ecoinvent data set for drying of feed grain (Nemecek and Kägi 2007) and the amount of water to be evaporated. The latter corresponds to $0.33 \mathrm{~kg}$ water per $\mathrm{kg}$ crab shell in wet weight, assuming that the initial moisture is $40 \%$ (GAMS 2010) and final moisture is $10 \%$ according to the chitosan manufacturer.

Dry crab shells are transported to the port in Canada, where we assume an average distance of $100 \mathrm{~km}$. For maritime transport, we used a distance of $13,722 \mathrm{~nm}(25,413 \mathrm{~km})$, between the coast of New Foundland and Qingdao (Ports.com 2016). From Qingdao port to the chitin manufacturer, the average distance is $100 \mathrm{~km}$. All transport services were modelled with ecoinvent data sets for road and sea freight transport.

Primary data on chitin production in China were collected by the European chitosan producer, directly from its chitin supplier. This process requires $10 \mathrm{~kg}$ dry crab shell per $\mathrm{kg}$ chitin and consumes $1.2 \mathrm{kWh}$ electricity, $6 \mathrm{~kg}$ coal for heating purposes, $9 \mathrm{~kg} \mathrm{HCl}$ (6\% vol.), $8 \mathrm{~kg} \mathrm{NaOH}$ (4\% vol.) and $300 \mathrm{~L}$ freshwater, also per $\mathrm{kg}$ chitin. Land occupation was estimated at $0.07 \mathrm{~m}^{2}$ yr per $\mathrm{kg}$ chitin. The release of $\mathrm{CO}_{2}$ from treatment of shells with acid was estimated at $0.9 \mathrm{~kg} \mathrm{CO}_{2}$ per $\mathrm{kg}$ chitin, based on their carbon content and stoichiometry. Solid waste from chitin production includes wastewater and protein sludge. The amount of wastewater produced as well as its treatment was not reported by the chitin producer. The wastewater volume was estimated assuming that it equals the freshwater input (process water plus water in chemical solutions), 
and in terms of treatment, it was assimilated to urban wastewater, being treated according to the ecoinvent data set for average wastewater (Doka 2007). The amount of protein sludge recovered from wastewater was estimated based on the crab waste composition and assuming recovery of $75 \%$ of the protein fraction. This percentage assumes that the Chinese chitin producer has the same protein recovery efficiency as Mahtani in India. Based on these assumptions, we estimated that $2.84 \mathrm{~kg}$ protein in dry mass is recovered per $\mathrm{kg}$ chitin. This material is used as animal feed according to the chitin producer, thus displacing the marginal supply of feed protein in the market (soybean meal; see Sect. 3.1).

Chitin is shipped to Europe. We assumed an average distance of $100 \mathrm{~km}$ from the chitin producer to the port. For maritime transport, we used a distance of $12,351 \mathrm{~nm}$ $(22,874 \mathrm{~km})$ between Qingdao and Rotterdam (Ports.com 2016). From Rotterdam to the chitosan manufacturer, we added $500 \mathrm{~km}$ of road transport.

Primary data on chitosan production for medical applications were provided by the European producer based on their own operations. The data collected included the chitin-tochitosan yield, freshwater input, use of chemicals $(\mathrm{NaOH})$, electricity use, land occupation and production of wastewater and waste $\mathrm{NaOH}$ for disposal. Unfortunately, the primary data are confidential and the figures cannot be disclosed in this publication. For this reason, in the supplementary material, we provide an inventory table for this process, where figures are not shown but where the background data sets used can be seen. As in chitin production, wastewater was assimilated to average urban wastewater and modelled with the same data set for wastewater treatment. Finally, data on disposal of waste $\mathrm{NaOH}$ solutions was not available. This waste is managed by a dedicated company in Europe, and it is judged by the chitosan producer that waste is subject to neutralisation. We included in the inventory an estimate of the transport, acid consumption for neutralisation and subsequent treatment of the solution in a municipal wastewater treatment plant.

\section{Results and discussion}

Figures 3, 4, 5, and 6 show the life cycle impact assessment (LCIA) results for the two chitosan supply chains, from cradle to gate. In order to simplify the interpretation of these results, the figures only display 5 out of the 16 impact indicators included in the ILCD method, whereas in the supplementary material, we provide the detailed LCIA results for all impact categories.

\subsection{Indian chitosan}

Figure 3 shows the relative contribution of several life cycle stages to the cradle-to-gate impact of the Indian chitosan. This

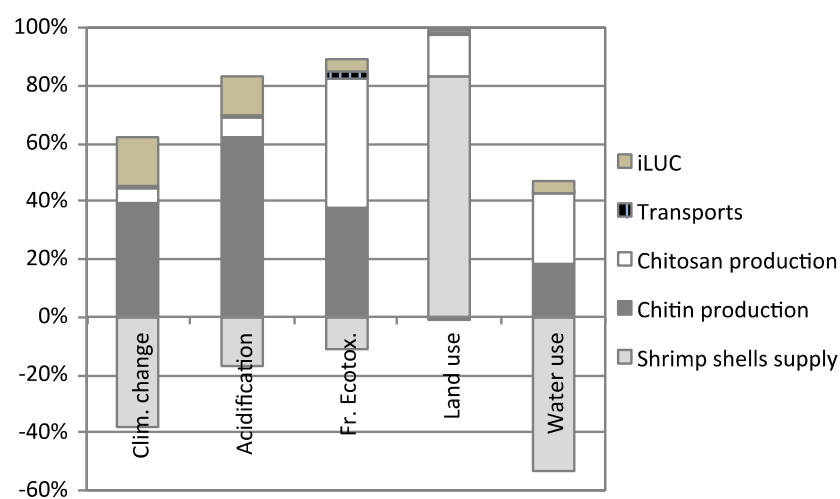

Fig. 3 Impact assessment results for general-purpose chitosan produced in India by life cycle stage

includes raw material acquisition (waste shells), transports, chitin production, chitosan production and iLUC. Indian chitosan production shows savings or credits (negative values in the graph) for several impact categories, especially in water use and climate change. In water use, the water saving is higher than the water use. These savings are associated to the diversion of shells from the animal feed market. This gap in the animal feed market is filled by barley and soybean meal production. When production of soybean meal is induced, soy oil is co-produced, and as seen in Fig. 1, this oil substitutes palm oil in the market. The credits in Fig. 3 are mainly associated by the displaced palm oil production, although in land use, this does not lead to a credit but to an impact, caused by land used to cultivate soybean and barley. The chitin production step dominates climate change and acidification impacts, whilst both chitin and chitosan production steps are equally important in ecotoxicity and water use. iLUC in the Indian chitosan supply chain is associated to diverting shrimp shells from animal feed production. As already mentioned, this creates an additional demand for soybean and barley, thus creating pressure to either put new land into cultivation, via deforestation, or by increasing yields in currently cultivated land. The effect of iLUC is relevant in the results, especially in climate change and acidification. In climate change, this is associated to $\mathrm{CO}_{2}$ emissions from

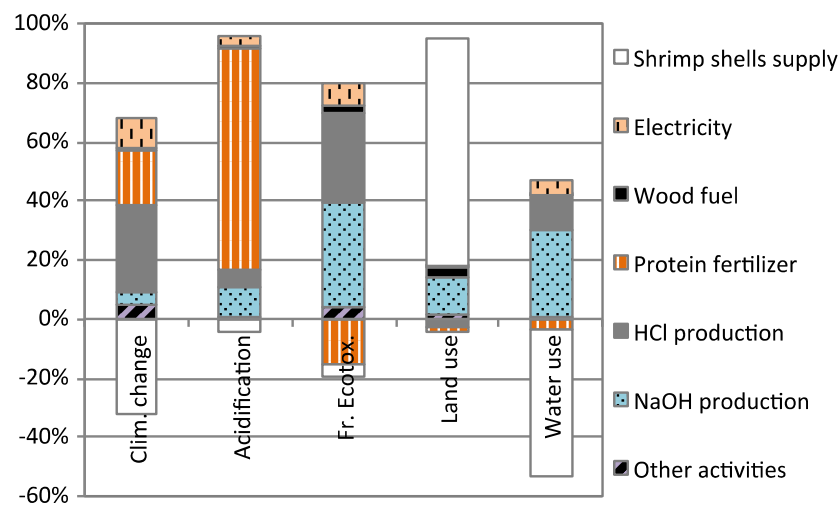

Fig. 4 Impact assessment results for general-purpose chitosan produced in India by activity 


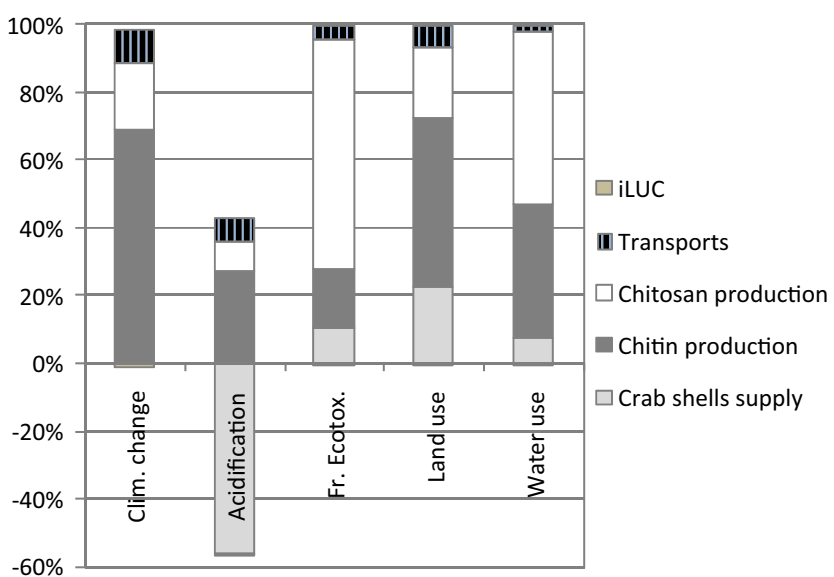

Fig. 5 Impact assessment results for chitosan for the medical sector produced in Europe by life cycle stage. Chitosan production stage is based on confidential inventory data (see supplementary material)

deforestation, whilst in all the other impact categories, it is associated to production of nitrogen fertilizers to increase crop yields (Schmidt et al. (2015). It can also be seen that the contribution of transports is negligible, since all activities in the foreground system are located in the same area in Gujarat.

Figure 4 gives some insights as to why certain life cycle stages dominate in Indian chitosan production, as this figure disaggregates life cycle stages into individual activities. The impact of chitin production in climate change and acidification is mainly related to the consumption of $\mathrm{HCl}$, as well as to the ammonia emissions produced when protein sludge is used as fertilizer. The impact of the chitosan production step is mainly related to consumption of $\mathrm{NaOH}$. Overall, the contribution of energy use (heat and electricity) for Indian chitosan is relatively low, as well as the $\mathrm{CO}_{2}$ emissions from treatment of shells with acid (included under 'other activities' in Fig. 4).

\subsection{European chitosan}

Figure 5 shows the relative contribution of several life cycle stages to the cradle-to-gate impact of the chitosan produced in Europe. As in the Indian case, the acquisition of waste shells is

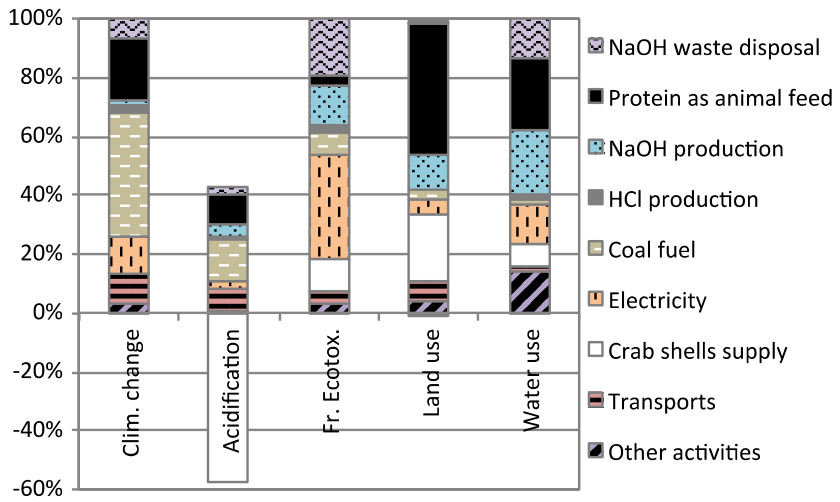

Fig. 6 Impact assessment results for chitosan for the medical sector produced in Europe by activity associated with a credit, although in this case, it is only relevant in the acidification impact indicator. Crab shells are diverted from a composting process, thereby avoiding the ammonia emissions associated to composting. These avoided acidifying emissions are higher than those released in the chitosan supply chain, resulting in a net beneficial effect; i.e. demanding chitosan implies a reduction in acidification impacts, compared to a situation where crab shells were instead composted. It can be seen in Fig. 5 that chitin production dominates the climate change indicator as well as land use, whilst chitosan production dominates freshwater ecotoxicity. Water use is almost equally influenced by chitin and chitosan production. As for transports, it can be seen that their influence is relatively small, although higher than in the Indian case, given that crab shells and chitin are transported over long distances. Finally, the effect of iLUC is negligible for European chitosan. This is due to the fact that its raw material is not linked to crops through the animal feed market.

In Fig. 5, the life cycle stages for European chitosan are disaggregated into individual activities. It can be seen that energy use plays a key role; the use of coal as fuel during chitin production as well as the overall electricity use dominate climate change, acidification and ecotoxicity impacts. Both $\mathrm{HCl}$ and $\mathrm{NaOH}$ play a less important role in this supply chain compared to the Indian one when looking at the graph; however, the impact of $\mathrm{HCl}$ production is higher, since the $\mathrm{NaOH}$ disposal process is mainly influenced by the amount of $\mathrm{HCl}$ required to neutralise the waste $\mathrm{NaOH}$ solution. Finally, the use of protein waste from chitin production as animal feed results in a substantial contribution to all indicators except ecotoxicity. This is due to the fact that the substitution of soybean meal by this chitin waste results in additional production of palm oil and barley.

\subsection{Relative comparison of the two supply chains}

Figure 7 shows a comparison of the two supply chains in relative terms. The goal of this comparison is just to understand differences between the two product systems, rather than to determine which product is more sustainable. The Indian chitosan supply chain appears to have a lower impact in climate change, freshwater ecotoxicity and water use, whereas the European supply chain has a lower impact in acidification. The difference in land use is less marked. In the supplementary material, it can be seen that in general terms, the Indian supply chain leads to lower impact scores in most indicators. A key driver for the higher impact of the European chitosan supply chain is its higher energy intensity. When calculated as its cumulative energy demand (not shown in the results), the European supply chain requires four times as much primary energy (both renewable and fossil) as the Indian one. 


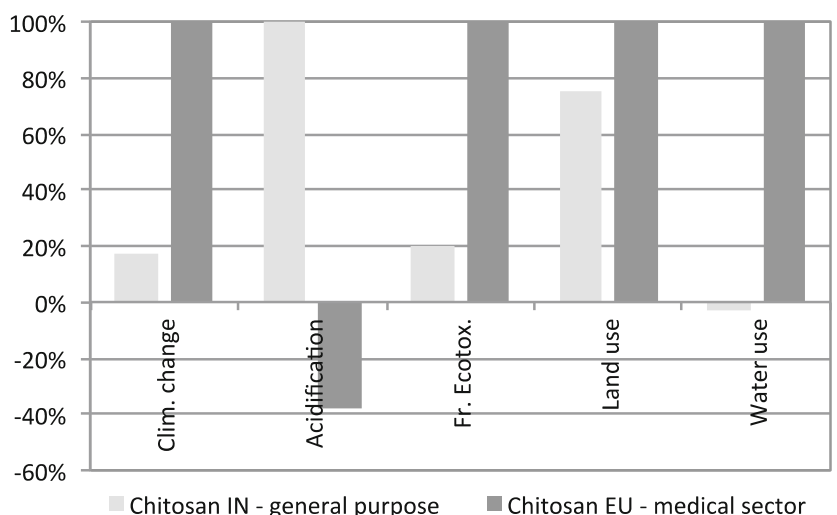

Fig. 7 Comparison of impact assessment results for Indian and European chitosan supply chains in relative terms. The highest score in each impact indicator is set to $100 \%$

\subsection{Discussion}

\subsubsection{Differences between the two supply chains}

Although we have assessed two products of the same family, with similar raw materials (crustacean shells) and production principles, our results show that the difference in environmental impact from cradle to gate is extremely variable with differences of up to one order of magnitude, depending on the indicator. It must be highlighted that the goal of this comparison is not to establish which chitosan is more sustainable, since the products assessed target different markets and comparing them is not straightforward; the chitosan by Mahtani is used in applications such as agriculture, amongst others, whereas the European producer is entirely focused on the medical sector. From the data collected for this study, it is not possible to establish to what extent the impact assessment results obtained are driven by the type of market targeted and its more or less stringent quality standards or by the characteristics of the supply chain and technology context/choices. It can be concluded, though, that on the one hand, the Indian chitosan supply chain relies less on fossil energy, and this gives it an advantage on energy-related environmental impacts. On the other hand, the diversion of crab waste from composting gives the European chitosan an advantage on acidification (ammonia and $\mathrm{NO}_{\mathrm{x}}$ emissions). Another advantage of the European chitosan supply chain is that its raw material does not influence crop production through the animal feed market, and this leads to a negligible effect on iLUC.

\subsubsection{Limitations and data gaps}

This is to our knowledge the first LCA study applied to chitosan production using only primary data from real producers. Nevertheless, the data collected was not complete and several aspects were either missing or uncertain. This is especially the case for the European supply chain due to its higher complexity and the associated difficulties in acquiring data the further one gets from the direct manufacturer activities. For those activities directly controlled by this manufacturer, the data can be considered of high quality, although we cannot disclose the actual figures for confidentiality reasons.

In the Indian case, on the other hand, all processes take place locally in Gujarat, India, meaning that most data are within reach of the manufacturer. Below, we list the most important limitations and data gaps encountered for the two supply chains.

For European chitosan,

- Specific data on drying of crab shells was not available, and this process was assimilated to grain drying. However, this process is not judged to drive the uncertainty in the model as the moisture to be removed is relatively low (0.33 kg water $/ \mathrm{kg}$ fresh shells).

- Emissions associated to composting of crab shells were not measured from actual composting plants but estimated based on literature and mass balances. In practice, composting plants mix different waste streams; therefore, emissions from measurements would not reflect those from shells only. It is judged that our calculations provide the emissions at the right order of magnitude. On the other hand, it is unknown to us to what extent the energy use reported in the ecoinvent data set for composting is different to actual Canadian plants composting crab waste.

- Data on management of spent $\mathrm{NaOH}$ solutions generated during chitosan production were entirely based on assumptions by the European manufacturer and the authors. The impact of this process is not negligible due to the consumption of acid to neutralise the solution. Again, it is unknown to us to what extent our estimate deviates from reality.

- Data on composition of wastewaters generated during chitin and chitosan production were not available. We have covered treatment of wastewater assuming the same composition and treatment than conventional urban wastewater, which might be far from reality. It is uncertain whether chitin production effluents are subject to treatment in China, where only one third of the population are connected to wastewater treatment plants (OECD 2016).

For Indian chitosan,

- iLUC is one of the main contributors to climate change and acidification impacts. We are aware that the iLUC model by Schmidt et al. (2015) is one amongst many other models and that there is currently no consensus in the LCA community on how to model iLUC.

For both supply chains, data on infrastructure (buildings, etc.) used in the chitin and chitosan production processes were 
not available beyond land occupation. We filled this gap by means of generic data sets for the chemical industry available in the ecoinvent database, but we feel that this is a rather poor approximation, as these are data sets based on the chemical industry in Europe. Even for the European producer, this might not be appropriate, since the data refer to a large factory rather than one producing low volumes of speciality chemicals. Therefore, although production of infrastructure has not appeared as a hot spot for any of the two chitosans (see supplementary material and Sect. 2), this remains as another aspect for improvement in future studies.

\section{Conclusions}

We have presented what to our knowledge is the first cradleto-gate LCA of chitosan production based on primary data from industry, namely two producers in India and Europe. Furthermore, this is the first study to assess this product using consequential modelling principles, thereby addressing on a prospective way the consequences of demanding chitosan, rather than reporting the impacts of the supply chain on a retrospective way. Even though we have assessed two products from the same family, the results show that they have very different environmental profiles, reflecting their substantially different supply chains in terms of raw material (shrimp shells vs. crab shells), production locations (locally produced vs. a global supply chain involving three continents) and the different applications (general-purpose chitosan vs. chitosan for the medical sector).

In the Indian supply chain, the production of chemicals $(\mathrm{HCl}$ and $\mathrm{NaOH})$ appears as an important hot spot. The use of shrimp shells as raw material affects the market for animal feed, resulting in a credit in many impact indicators, especially in water use, where the net result is a water saving. The use of protein waste as fertilizer is also an important source of greenhouse-gas and ammonia emissions. In the European supply chain, energy use is the key driver for environmental impacts, namely heat production based on coal in China and electricity production in China and Europe. The use of crab shells as raw material avoids the composting process they would be otherwise subject to, leading to a saving in composting emissions, especially ammonia, which has a key contribution to acidification. In the Indian supply chain, the effect of iLUC is relevant, given that using shrimp shells diverts them from the animal feed market, thus inducing land conversion to produce crops (soybean and barley) to fill this gap in the market. In the European supply chain, on the other hand, the effect of iLUC is negligible, since using crab shells does not currently affect the animal feed market.

Although this study used high-quality data from two real producers, not all relevant information were available, especially for the European chitosan, which involves a more complex supply chain. In spite of this, this study provides insights to these two companies on their global environmental impacts and provides a benchmark for future studies, assessing chitosan production using different raw materials and/or production methods, such as bio-engineering.

Acknowledgement The authors thank the EU's Seventh Framework Programme for research, technological development and demonstration for its financial assistance through the Nano3bio project (grant agreement number 613931).

Open Access This article is distributed under the terms of the Creative Commons Attribution 4.0 International License (http:// creativecommons.org/licenses/by/4.0/), which permits unrestricted use, distribution, and reproduction in any medium, provided you give appropriate credit to the original author(s) and the source, provide a link to the Creative Commons license, and indicate if changes were made.

\section{References}

Agnihotri SA, Mallikarjuna NN, Aminabhavi TM (2004) Recent advances on chitosan-based micro- and nanoparticles in drug delivery. J Control Release 100:5-28

Bautista-Baños S, Hernández-Lauzardo AN, Velázquez-del Valle MG, Hernández-López M, Barka EA, Bosquez-Molina E, Wilson CS (2006) Chitosan as a potential natural compound to control pre and postharvest diseases of horticultural commodities. Crop Prot 25:108-118

Beach E, Eckelman MJ, Cui Z, Brentner L, Zimmerman JB (2012) Preferential technological and life cycle environmental performance of chitosan flocculation for harvesting of the green algae Neochloris oleoabundans. Bioresource Technol 121:445-449

Doka G (2007) Life cycle inventories of waste treatment services. Final report ecoinvent 2000 No. 13, EMPA St. Gallen, Swiss Centre for Life Cycle Inventories, Duebendorf, Switzerland

Cabrera JC, Messiaen J, Cambier P, Van Cutsem P (2006) Size, acetylation and concentration of chitooligosaccharide elicitors determine the switch from defense involving PAL activation to cell death and water peroxide production in Arabidopsis cell suspensions. PhysiologiaPlantarum 127:44-56

Ecoinvent Centre (2016) The ecoinvent database. http://www.ecoinvent. org/database/database.html (accessed 2 September 2016)

Ekvall T, Weidema BP (2004) System boundaries and input data in consequential life cycle inventory analysis. Int $\mathrm{J}$ Life Cycle Assess 9(3):161-171

FAO and IFA (2001) Global estimates of gaseous emissions of $\mathrm{NH}_{3}$, NO and $\mathrm{N}_{2} \mathrm{O}$ from agricultural land. Food and Agriculture Organization of the United Nations (FAO) and International Fertilizer Industry Association (IFA), Rome, Brussels, Belgium

Frischknecht R, Steiner R, Jungbluth N (2008) Methode der ökologischen Knappheit - Ökofaktoren 2006. ö.b.u. und Bundesamt für Umwelt, Bern

GAMS (2010) Feasibility of producing value added products from snow crab processing waste in Cape Breton, Nova Scotia. Submitted to Nova Scotia Department of Fisheries and Aquaculture by the Gulf Aquarium and Marine Station Cooperative. GAMS, C.P.697, Cheticamp, Nova Scotia

GIA (2005) Chitin \& chitosan. A Global Strategy Business Report. Global Industry Analyst, INC. July 2005

Haberl H, Erb KH, Krausmann F, Gaube V, Bondeau A, Plutzar C, Gingrich S, Lucht W, Fischer-Kowalski M (2007) Quantifying and 
mapping the human appropriation of net primary production in Earth's terrestrial ecosystems. PNAS 104(31):12942-12947

ISO (2006a) ISO 14040 - environmental management-life cycle assessment-principles and framework. International Standard Organization (ISO), Genève

ISO (2006b) ISO 14044 environmental management - life cycle assessment - requirements and guidelines. International Standard Organization (ISO), Genève

Jeon YJ, Shahidi F, Kim SK (2000) Preparation of chitin and chitosan oligomers and their applications in physiological functional foods. Food Rev Int 16:121-157

JRC-IES (2010) ILCD handbook — general guideline for life cycle assessment - detailed guidance. First edition (March 2010). Institute for Environment and Sustainability (IES), Ispra

Jull AB, Ni Mhurchu C, Bennett DA, Dunshea-Mooij CAE, Rodgers A (2008) Chitosan for overweight or obesity. Cochrane database of systematic reviews, 2008, Issue 3. Art. No.: CD003892

Kendra DF, Hadwiger LA (1984) Characterization of the smallest chitosan oligomer that is maximally antifungal to Fusarium solani and elicits pisatin formation in Pisumsativum. Exp Mycol 8:276-281

Kim SK, Rajapakse N (2005) Enzymatic production and biological activities of chitosan oligosaccharides (COS): a review. Carbohyd Polym 62:357-368

Leceta I, Guerrero P, Cabezudo S, de la Caba K (2013) Environmental assessment of chitosan-based films. J Clean Prod 41:312-318

Mathur SP, Daigle JY, Brooks JL, Lévesque M, Arsenault J (1988) Composting seafood wastes. Biocycle, September 1988

Muñoz I, Schmidt J H, de Saxcé M, Dalgaard R, Merciai S (2015) Inventory of country-specific electricity in LCA - consequential scenarios. Version 3.0. 2.-0 LCA consultants, Aalborg, Denmark

Muñoz I, Milài Canals L, Clift R (2008) Consider a spherical man: a simple model to include human excretion in life cycle assessment of food products. J Ind Ecol 12(4):521-538

Nemecek T, Kägi T (2007) Life cycle inventories of agricultural production systems. Ecoinvent report no 15, Swiss Centre for Life Cycle Inventories, Zürich and Dübendorf, Switzerland

OECD (2016) Wastewater treatment (\% population connected). http:// stats.oecd.org/index.aspx? DataSetCode=water_treat\# (accessed 9 September 2016)
Paul W, Sharma CP (2004) Chitosan and alginate wound dressings: a short review. Trends in Biomaterials and Artificial Organs 18(1):18-23

Ports.com (2016) Sea route \& distance. http://ports.com/sea-route/ (accessed 2 September 2016)

Goedkoop MJ, Heijungs R, Huijbregts M, De Schryver A, Struijs J, Van Zelm R (2013) ReCiPe. A life cycle impact assessment method which comprises harmonized category indicators at the midpoint and the endpoint level. Ministry of Housing, Spatial Planning and Environment (VROM), the Netherlands

Schmidt JH, Dalgaard R (2012) National and farm level carbon footprint of milk-methodology and results for Danish and Swedish milk 2005 at farm gate. Arla Foods, Aarhus Accessed October 2012: http://www.lca-net.com/ArlaMain

Schmidt JH, Weidema BP, Brandão M (2015) A framework for modelling indirect land use changes in life cycle assessment. J Clean Prod 99(15):230-238

Schmidt JH (2015) Life cycle assessment of five vegetable oils. J Clean Prod 87(15):130-138

Smith A, Brown K, Ogilvie S, Rushton K, Bates J (2001) Waste management options and climate change. Final report to the European Commission. DG Environment, AEA Technology

Soliva M (2001) Compostatge i gestió de residusorgànics. Estudis i monografies. Àrea de MediAmbient, Diputació de Barcelona, Spain

Vander P, Vårum KM, Domard AEI, Gueddari NE, Moerschbacher BM (1998) Comparison of the ability of partially $\mathrm{N}$-acetylated chitosans and chitooligosaccharides to elicit resistance reactions in wheat leaves. Plant Physiol 118:1353-1359

Weidema BP, Ekvall T, Heijungs R (2009) Guidelines for applications of deepened and broadened LCA. Deliverable D18 of work package 5 of the CALCAS project. http://www.leidenuniv.nl/cml/ssp/ publications/calcas_report_d18.pdf (accessed 18 July 2016)

Weidema BP, Bauer C, Hischier R, Mutel C, Nemecek T, Reinhard J, Vadenbo CO, Wernet G (2013) Overview and methodology. Data quality guideline for the ecoinvent database version 3 . Ecoinvent Report 